\title{
Analisis Gangguan Tiga Fasa Seimbang Menggunakan Pendekatan Metode Radial Equivalent Independent DIMO Pada Sistem Interkoneksi Sulbagsel
}

\author{
Andi Nurtrimarini Karim ${ }^{*}$, Sri Mawar Said ${ }^{1}$, Indar Chaerah Gunadin ${ }^{1}$ \\ ${ }^{1}$ Departemen Teknik Elektro, Fakultas Teknik, Universitas Hasanuddin \\ Jl. Poros Malino Km. 6, Bontomarannu, Kabupaten Gowa, Sulawesi Selatan, 92171 \\ *Email: andinurtrimarini@gmail.com
}

DOI: 10.25042/jpe.052018.14

\begin{abstract}
Abstrak
Makalah ini menyajikan analisis gangguan transient tiga fasa seimbang pada system interkoneksi Sulawesi Bagian Selatan (Sulbagsel). Sistem interkoneksi Sulbagsel yang multi mesin dan sangat kompleks tentu sangat berpengaruh pada perubahanperubahan kondisi pada sistem, baik itu saat terjadinya hubung singkat maupun perubahan beban yang tiba-tiba pada system. Melalui pendekatan Metode Radial Equivalent Independent Dimo (REI-Dimo) maka akan dilakukan studi analisis system interkoneksi Sulbagsel yang terdiri dari 44 bus, 15 generator, 47 line, dan 34 beban yang selanjutnya akan di reduksi untuk mendapatkan bus generator terlemah serta arus gangguan terbesar pada bus. Hasil analisis diperoleh bahwa saat dilakukan simulasi hubung singkat didapatkan bus terlemah berada pada bus generator 2 (Pinrang) dengan nilai tegangan rata-rata selama gangguan sebesar $0.6492 \mathrm{pu}$. Sementara untuk arus gangguan terbesar terjadi pada bus 12 (Sengkang) yakni sebesar 29.9189 pu.
\end{abstract}

\begin{abstract}
Analysis of Balanced Three Phase Fault Using Radial Equivalent Independent (REI) Dimo Approach in Sulbagsel Interconnection System. This paper presents a three-phase transient transient disturbance analysis in South Sulawesi interconnection system (Sulbagsel). Sulbagsel multi-machine and highly complex interconnection system is certainly very influential on changes in the condition of the system, whether during short circuit or sudden changes in the system load. Through the approach of Radial Equivalent Independent Dimo (REI-Dimo) method, we will analyze the interconnection system of Sulbagsel system consisting of 44 bus, 15 generator, 47 line, and 34 load which will be reduced to get the weakest generator bus and the biggest disturbance flow bus. The result of analysis shows that when simulation of short circuit is obtained the weakest bus is on bus generator 2 (Pinrang) with average voltage value during interruption of 0.6492 pu. While for the biggest interference flow occurs in bus 12 (Sengkang) which amounted to 29.9189 pu..
\end{abstract}

Kata Kunci: Hubung singkat, REI-Dimo, sulbagsel, transient stability

\section{Pendahuluan}

Sistem tenaga listrik secara umum terdiri dari unit-unit pembangkit yang terhubung dengan saluran untuk melayani beban [1]. Sistem tenaga listrik yang memiliki banyak mesin biasanya menyalurkan daya kebeban melalui saluran interkoneksi [2-3]. Tujuan utama dari sistem saluran interkoneksi adalah untuk menjaga kontinuitas dan ketersediaan tenaga listrik terhadap kebutuhan beban yang terus meningkat. Semakin berkembang sistem tenaga listrik dapat mengakibatkan lemahnya performansi sistem ketika mengalami gangguan dan sangat berpengaruh pada kestabilan system [4].
Kestabilan sendiri terbagi atas tiga bagian besar yakni steady state stability, dynamic stability dan transient stability [5]. Penelitian ini akan menitik beratkan pada pembahasan stability transient pada system kelistrikan Sulawesi Bagian Selatan (Sulbagsel).

Berubahnya tupologi jaringan berdampak pada aliran daya yang akan berpengaruh pada stabilitas saat terjadinya gangguan transient pada system. Sistem yang besar dan kompleks serta perubahan kondisi sistem yang seketika [6], biasanya terjadi akibat adanya gangguan hubung singkat pada sistem tenaga listrik, dan pelepasan atau penambahan beban yang besar secara tiba-tiba. 
Akibat adanya perubahan kondisi kerja dari sistem ini, maka keadaan sistem akan berubah dari keadaan lama ke keadaan baru. Periode singkat di antara kedua keadaan tersebut disebut periode paralihan atau transient. Stabilitas transient didasarkan pada kondisi kestabilan ayunan pertama (first swing) dengan periode waktu penyelidikan pada detik pertama terjadi gangguan. Untuk menganailis hal tersebut maka digunakan metode Radial Equivalent Independent Dimo atau yang biasa dikenal dengan istilah REI-Dimo.

\section{Penentuan Steady State dan Transient Stability}

Dalam menganalisa suatu sistem tenaga listrik biasa digunakan beberapa metode. Metode kriteria sama luas (Equal Area Criterion atau EAC) merupakan contoh metode langsung untuk memperoleh waktu pemutusan kritis (Critical Clearing Time). Tapi metode ini terbatas untuk satu mesin saja dengan bus infinite (Single Machine Infinite Bus). Metode ini tidak cocok dipakai untuk menganalisa sistem yang sangat kompleks.

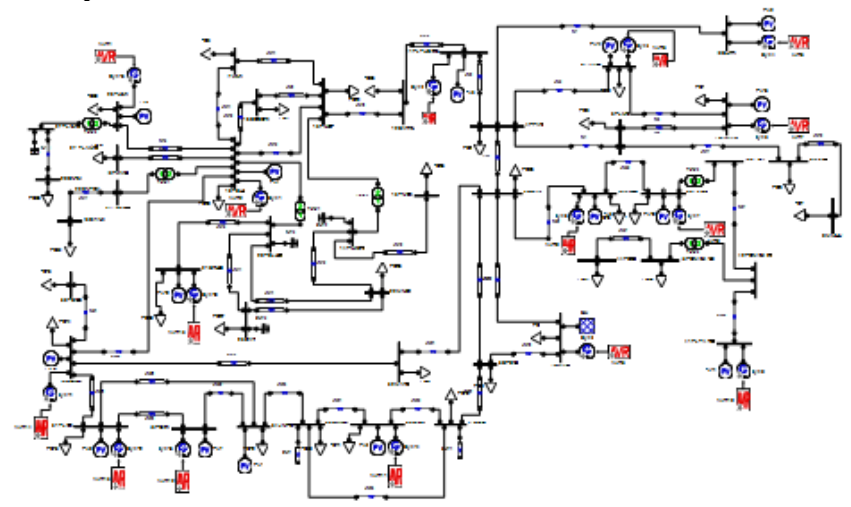

Gambar 1. Single line jaringan 44 bus Sulbagsel

Metode aliran daya (load flow) biasanya digunakan untuk menghitung total pembebanan dengan cara menambah pembebanan sampai proses load flow menjadi tidak konvergen. Metode ini biasanya menggunakan metode newtonraphson yang merupakan pengembangan dari metode gauss-seidel yang diperluas dan disempurnakan. Metode ini dibentuk berdasarkan matriks admitansi (Ybus).
Ada juga yang disebut metode continuation power flow (CPF) yang digunakan untuk menentukan hubungan antara loading parameter terhadap tegangan pada bus. Metode CPF dilakukan dengan reformulasi persamaan aliran daya (load flow) dengan menambahkan parameter pembebanan, yang diekspresikan sebagai berikut :

$$
\mathrm{F}(\theta, \mathrm{V})=\Lambda \mathrm{k}
$$

\section{Dimana :}

$\lambda=$ parameter beban

$\theta=$ vektor dari sudut tegangan bus

$\mathrm{V}=$ vektor dari besar tegangan bus

$\mathrm{K}=$ vektor yang menggambarakan presentase perubahan beban pada tiap bus

\section{Metode Newthon Rapson}

Metode Newton Rapshon digunakan dalam penyelesaian masalah aliran daya merupakan pengembangan dari deret taylor untuk suatu fungsi dua variable atau lebih. Untuk memahami metode ini dimulai dengan suatu pembahasan tentang penyelesaian suatu persoalan yang hanya terdiri dari dua persamaan dan dua variable. Kemudian melihat bagaimana pengembangan analisis ini untuk penyelesaian persamaan-persamaan aliran daya

Untuk menerapkan metode Newton-Rapshon pada penyelsaian persamaan-persamaan aliran daya dapat dipilih untuk menyatakan tegangan pada bus dan admitansi tiap saluran dalam bentuk polar. Bus slack tidak disertakan dalam penyelesaian iterasi untuk menentukan tegangan, karena besarannya sudah ditetapkan. Untuk menghitung nilai $\mathrm{P}$ dan $\mathrm{Q}$ kita dari masing-masing variable maka di dituliskan contoh persamaan matriks untuk suatu sistem yang hanya terdiri dari tiga buah bus. Jika bus nomor 1 adalah bus slack, maka perhitungan dimulai dari bus nomor 2 karena besar dan sudut untuk bus slack sudah ditentukan.

Dalam bentuk matriks dapat dilihat: 


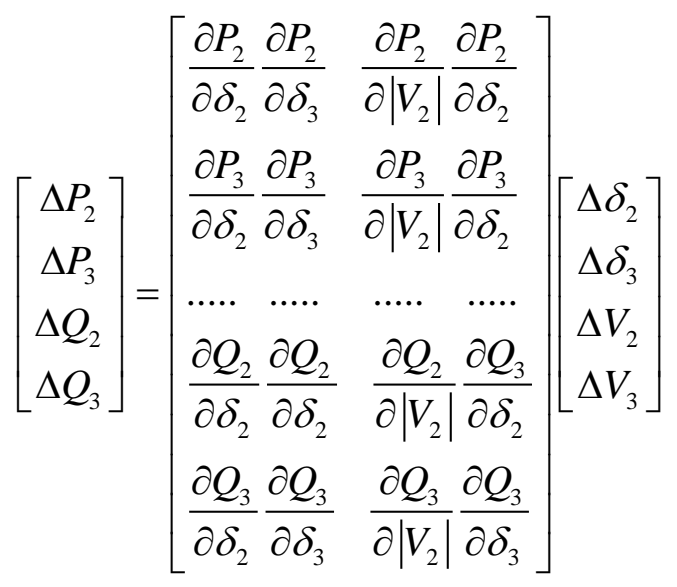

Elemen-elemen jacobian diperoleh dengan membuat turunan parsial dari rumus-rumus $\mathrm{P}$ dan Q dan mensubstitusi tegangan-tegangan perkiraan untuk iterasi pertama atau iterasi sebelumnya. Jacobian dibuat untuk memperjelas adanya bermacam-macam jenis umum turunan parsial yang muncul pada masing-masing submatriks.

Persamaan-persamaan umum turunan parsial diatas dapat dituliskan :

$$
\begin{aligned}
& H: \frac{\partial P_{i}}{\partial \delta_{j}}=\left|V_{i} V_{j} V_{i j}\right| \sin \left(\delta_{i}-\delta_{j}-\theta_{i j}\right) \\
& \frac{\partial P_{i}}{\partial \delta_{j}}=\sum_{m=1}^{N}\left|V_{i} V_{j} V_{i j}\right| \sin \left(\delta_{i}-\delta_{j}-\theta_{i n}\right) \\
& N: \frac{\partial P_{i}}{\partial\left|V_{j}\right|}=\left|V_{i} Y_{i j}\right| \cos \left(\delta_{i}-\delta_{j}-\theta_{i j}\right) \\
& \frac{\partial P_{i}}{\partial\left|V_{j}\right|}=2\left|V_{i} Y_{i i}\right| \cos \theta_{i i}+ \\
& \sum_{m=1}^{N}\left|V_{i} Y_{i n}\right| \cos \left(\delta_{i}-\delta_{j}-\theta_{i n}\right) \\
& M: \frac{\partial Q_{i}}{\partial \delta_{j}}=\left|V_{i} V_{j} V_{i j}\right| \cos \left(\delta_{i}-\delta_{j}-\theta_{i j}\right) \\
& \frac{\partial Q_{i}}{\partial \delta_{j}}=\sum_{m=1}^{N}\left|V_{i} V_{j} V_{i n}\right| \cos \left(\delta_{i}-\delta_{j}-\theta_{i n}\right) \\
& N: \frac{\partial Q_{i}}{\partial\left|V_{j}\right|}=\left|V_{i} Y_{i j}\right| \sin \left(\delta_{i}-\delta_{j}-\theta_{i j}\right) \\
& \frac{\partial Q_{i}}{\partial\left|V_{i}\right|}=2\left|V_{i} Y_{i i}\right| \cos \theta_{i i}+ \\
& \sum_{\substack{m=1 \\
n \neq 1}}^{N}\left|V_{i} Y_{i n}\right| \sin \left(\delta_{i}-\delta_{j}-\theta_{i n}\right)
\end{aligned}
$$

Proses perhitungan aliran daya dengan metode Newton-Rapshon dapat diringkaskan dengan langkah-langkah berikut:

1. Menentukan nilai-nilai $\mathrm{P}_{\text {calc }}$ dan $\mathrm{Q}_{\text {calc }}$ yang mengalir kedalam sistem pada setiap bus untuk nilai yang ditentukan atau perkiraan dari besar dan sudut tegangan pada iterasi pertama atau tegangan yang ditentukan paling akhir pada iterasi berikutnya.

2. Menghitung $\Delta \mathrm{P}$ pada setiap bus.

3. Menghitung nilai jacobian dengan menggunakan nilai-nilai perkiraan atau yang ditentukan besar dan sudut tegangan.

4. Membalikkan (invers) jacobian itu dan menghitung koreksi-koreksi $\Delta \delta_{\mathrm{i}}$ dan $\Delta\left|\mathrm{V}_{\mathrm{i}}\right|$ pada tiap bus.

5. Menghitung nilai $\delta_{\mathrm{i}}$ dan $\left|\mathrm{V}_{\mathrm{i}}\right|$ yang baru dengan menambahkan $\Delta \delta_{\mathrm{i}}$ dan $\Delta\left|\mathrm{V}_{\mathrm{i}}\right|$ pada nilai sebelumnya.

6. Kembali ke langkah 1 dan mengulangi proses itu dengan menggunakan nilai untuk besar dan sudut tegangan yang baru didapatkan sampai semua nilai $\Delta \mathrm{P}$ dan $\Delta \mathrm{Q}$ lebih kecil dari suatu indeks ketelitian yang dipilih.

Jumlah iterasi yang diperlukan dalam metode Newton-Rapshon yang menggunakan admitansi bus praktis tidak tergantung pada jumlah bus. Di sisi lain, perhitungan elemen-elemen jacobian dan waktu yang diperlukan untuk tiap iterasi cenderung lebih panjang. Keuntungan dalam waktu computer yang lebih pendek untuk suatu penyelesaian dengan ketelitian yang sama menyebabkan metode Newton-Rapshon lebih banyak dipilih untuk senua sistem, kecuali yang sangat kecil.

\section{Metodologi penelitian}

\subsection{Studi Area}

Dalam melakukan penelitian Transient Stability tiga fasa seimbang pada sistem multi mesin dilakukan dengan cara memberikan gangguan pada setiap bus hasil reduksi. Penelitian yang dilakukan guna mengkaji transient stability menerapkan metode REI-DIMO yang kemudian diterapkan pada proses komputasi dan pengolahan data pada software perangkat lunak Matrix Laboratory (MATLAB). Studi kasus yang 
dijadikan test case yaitu sistem interkoneksi Sulbagsel terdiri dari 15 generator, 44 bus, 47 line dan 34 beban yang tersebar yang akan diteliti, dengan variasi tegangan dari $30 \mathrm{kV}, 70 \mathrm{kV}, 150 \mathrm{kV}$ dan $275 \mathrm{kV}$ [7].

Tabel 1. Nilai impedansi generator

\begin{tabular}{ccccc}
\hline No & Bus Generator & $\begin{array}{c}\mathbf{X} \text { 'd } \\
(\mathbf{p . u})\end{array}$ & ra & $\begin{array}{c}\text { Inersia } \\
\mathbf{H}\end{array}$ \\
\hline 1 & Bakaru & 0.3950 & 0 & 1.02 \\
\hline 2 & Pinrang & 0.2000 & 0 & 6.26 \\
\hline 3 & Suppa & 0.4080 & 0 & 2.61 \\
\hline 4 & PLTU Barru & 0.3680 & 0 & 5.41 \\
\hline 5 & Tello150 & 0.3680 & 0 & 2.97 \\
\hline 6 & Borongloe & 0.3950 & 0 & 5.56 \\
\hline 7 & Tellolama 150 & 0.3950 & 0 & 5.56 \\
\hline 8 & Sugguminasa & 0.3680 & 0 & 2.97 \\
\hline 9 & Tallasa & 0.2000 & 0 & 6.26 \\
\hline 10 & Punagaya & 0.4080 & 0 & 7.32 \\
\hline 11 & Sinjai & 0.3680 & 0 & 5.41 \\
\hline 12 & Sengkang & 0.3680 & 0 & 5.41 \\
\hline 13 & Makale & 0.3950 & 0 & 5.56 \\
\hline 14 & Palopo & 0.3680 & 0 & 2.97 \\
\hline 15 & PLTA Poso & 0.3950 & 0 & 5.56 \\
\hline
\end{tabular}

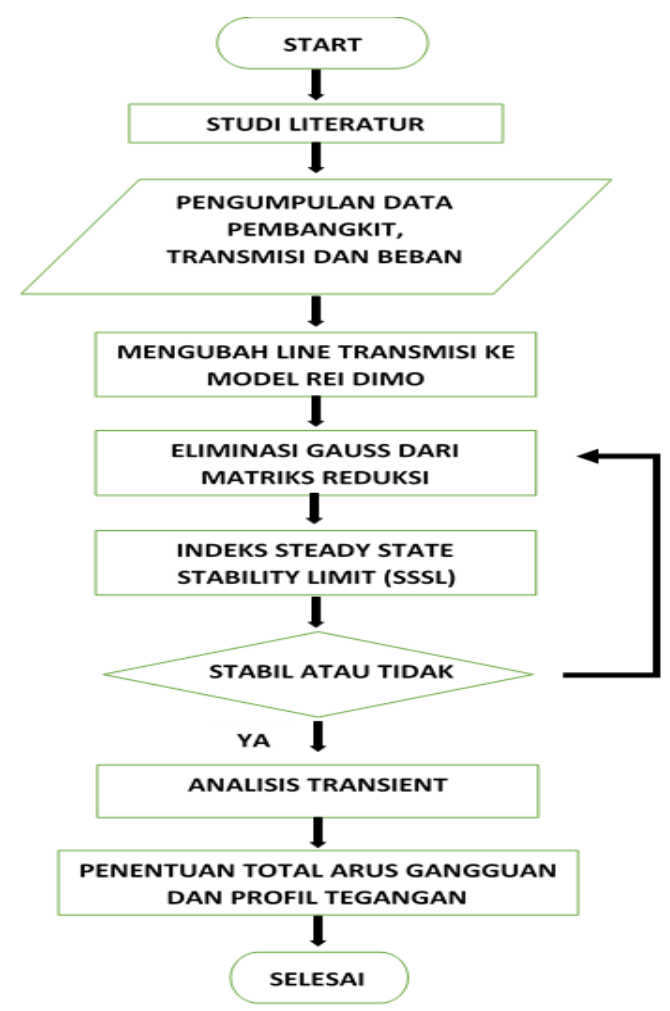

Gambar 2. Flowchart penelitian
Prosedur untuk menyelesaikan penelitian ini dapat dilihat pada flow chart penelitian Gambar 2. Langkah pertama dimulai dengan melakukan studi literature, mengumpulkan data untuk semua parameter mulai dari pembangkit, transmisi sampai data beban.

Setelah data sistem diperoleh maka dilakukan analisa power flow [8] untuk melihat respon tegangan dan aliran daya. Kemudian system direduksi menggunakan pendekatan Radial Equivalent Independent yang dikenal dengan Metode REI-Dimo. Selanjutnya dilakukan studi stabilitas dan Transient stability

\subsection{Konsep Metode REI-Dimo}

Menurut Indar Chaerah Gunadin [9]. Salah satu metode untuk menentukan batas steady state adalah metode REI Dimo yang dikembangkan oleh Paul Dimo. Analisis tegangan dan steady state menurut Paul Dimo didasarkan pada konsep berikut :

a. Menyederhanakan model sistem tenaga listrik - REI Net (Radial Equivalent and Independent Net).

b. Menggambarkan vektor dari short circuitNodal Image.

c. Menggunakan kriteria stabilitas untuk evaluasi tegangan dan steady state stability.

d. Terjadinya ketidakstabilan - case worsening procedure.

1. REI net atau REI Bus

Model sederhana dari sistem tenaga REI net memungkinkan untuk memeriksa setiap generator yang dilihat dari bus pada sistem. Bus generator dapat mewakili mesin sinkron nyata pada sistem tenaga.

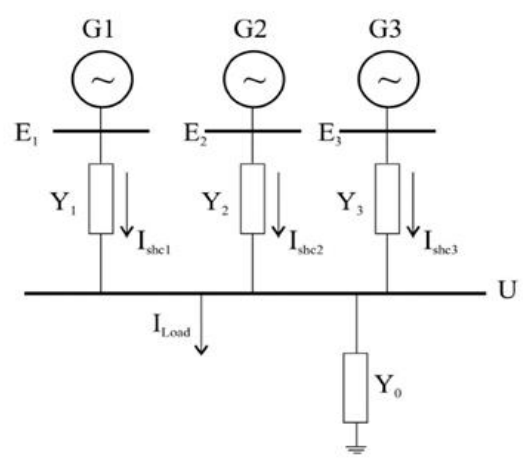

Gambar 3. REI net 


\section{Persamaan REI Dimo}

Metodologi REI-Dimo menggantikan jaring transmisi dengan admitansi konstan, kemudian diterapkan ke bus fiktif. Jaring ini disebut zero power balance network dan mewakili konsep utama dalam REI-Dimo.

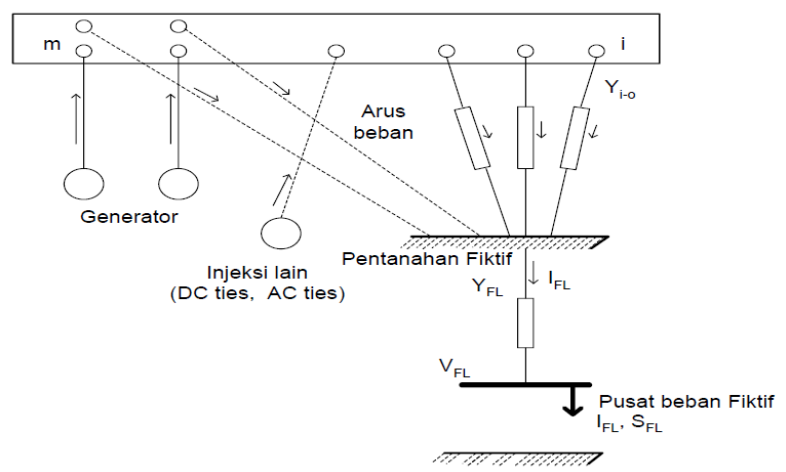

Gambar 4. Zero power balance network
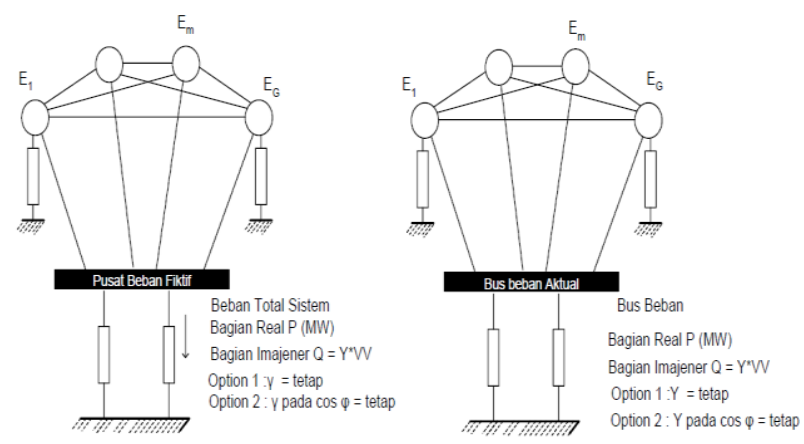

Gambar 5. REI bus beban fiktif dan Actual

3. Prosedur REI-Dimo

Menurut Rusilawati [10], Prosedur reduksi jaring sistem tenaga listrik yang diterapkan dapat dijelaskan sebagai berikut :

a. Menyiapkan data sistem tenaga listrik (dalam hal ini data sistem Sulbagsel)

b. Menjalankan load flow untuk mendapatkan tegangan dan sudut tegangan

c. Menentukan bus beban

d. Menentukan bus netral fiktif

e. Menghubungkan bus beban ke bus netral fiktif dengan admitansi Y bus konstan. Persamaan Y bus konstan adalah :

$$
Y_{b u s}=\frac{P+j Q}{V^{2}}
$$

f. Menentukan arus I dari bus beban ke bus netral fiktif dengan persamaan:

$$
I=\left(\frac{S^{*} i n}{E i-j F i}\right)
$$

g. Menentukan bus load center

h. Menentukan arus yang mengalir ke bus load center dengan menggunakan hukum Kirchoff

i. Menghitung daya yang menuju ke bus netral fiktif

j. Menentukan nilai impedansi $Z_{i c}$ dari bus netral fiktif ke bus load center dengan persamaan:

$$
R_{l c}+j X_{l c}=\left(\frac{P+j Q}{I x I^{*}}\right)
$$

k. Mengubah impedansi $\mathrm{Z}_{\mathrm{lc}}$ kedalam bentuk admitansi $Y_{l c}$

i. Menentukan tegangan pada load center dengan persamaan:

$$
V_{l c}=\frac{S_{l c}}{I^{*}{ }_{l c}}
$$

1. Menjalankan load flow untuk menghasilkan admitansi Y bus yang baru

m. Mereduksi matriks Y dengan Gaussian

n. Mengubah nilai admitansi $Y$ menjadi impedansi ekivalen $\mathrm{Z}$

o. Menganalisa batas aman steady state stability.

p. Menganalisa Transient Stability.

\section{Hasil dan Pembahasan}

Menggunakan metode REI-Dimo maka Admitansi Konstan dan Arus Beban disetiap busnya diketahui. Tabel 2 dibawah memperlihatkan hasil komputasi berdasarkan metode REI-Dimo guna mendapatkan nilai Admitansi konstan dan Arus beban pada setiap busnya.

Tabel 2. Admitansi konstan dan arus beban

\begin{tabular}{clcccc}
\hline No & Nama Bus & Voltage & $\begin{array}{c}\mathbf{G} \\
{[\mathbf{p u}]}\end{array}$ & $\begin{array}{c}\mathbf{B} \\
{[\mathbf{p u}]}\end{array}$ & $\begin{array}{c}\mathbf{I} \\
{[\mathbf{p u}]}\end{array}$ \\
\hline 1 & Bakaru & 1.030 & 0.033 & -0.002 & 0.034 \\
\hline 2 & Polmas & 0.998 & 0.172 & -0.041 & 0.171 \\
\hline 3 & Majene & 0.990 & 0.238 & -0.038 & 0.235 \\
\hline 4 & Mamuju & 0.983 & 0.099 & -0.050 & 0.098 \\
\hline 5 & Pinrang & 1.000 & 0.244 & -0.062 & 0.244 \\
\hline 6 & Parepare & 0.998 & 0.188 & -0.047 & 0.187 \\
\hline 7 & Suppa & 1.000 & 0.000 & 0.000 & 0.000 \\
\hline 8 & Sidrap & 0.985 & 0.273 & -0.106 & 0.269 \\
\hline 9 & Pltubarru & 1.000 & 0.000 & 0.000 & 0.000 \\
\hline
\end{tabular}




\begin{tabular}{llcccc}
\hline No & Nama Bus & Voltage & $\begin{array}{c}\text { G } \\
\text { [pu] }\end{array}$ & $\begin{array}{c}\text { B } \\
\text { [pu] }\end{array}$ & $\begin{array}{c}\text { I } \\
\text { [pu] }\end{array}$ \\
\hline 10 & Barru & 0.946 & 0.113 & -0.027 & 0.107 \\
\hline 11 & Pangkep150 & 0.936 & 0.252 & -0.091 & 0.236 \\
\hline 12 & Pangkep70 & 0.939 & 0.000 & 0.000 & 0.000 \\
\hline 13 & Tonasa & 0.909 & 0.229 & -0.128 & 0.208 \\
\hline 14 & Bosowa & 0.930 & 0.382 & -0.178 & 0.356 \\
\hline 15 & Kima & 0.934 & 0.206 & -0.066 & 0.193 \\
\hline 16 & Tello150 & 0.970 & 0.673 & -0.194 & 0.653 \\
\hline 17 & Panakukang & 0.950 & 0.757 & -0.196 & 0.719 \\
\hline 18 & Tello70 & 0.972 & 0.000 & 0.212 & 0.000 \\
\hline 19 & Borongloe & 1.000 & 0.114 & 0.000 & 0.114 \\
\hline 20 & Mandai & 0.942 & 0.274 & -0.029 & 0.258 \\
\hline 21 & Daya & 0.948 & 0.507 & -0.031 & 0.480 \\
\hline 22 & Tello30 & 0.970 & 0.000 & 0.000 & 0.000 \\
\hline 23 & Barawaja & 0.971 & 0.000 & 0.000 & 0.000 \\
\hline 24 & Tellolama150 & 0.970 & 0.209 & -0.050 & 0.203 \\
\hline 25 & Tellolama70 & 0.944 & 0.000 & 0.000 & 0.000 \\
\hline 26 & Bontoala & 0.926 & 0.309 & -0.090 & 0.286 \\
\hline 27 & Sungguminasa & 0.980 & 0.163 & -0.037 & 0.160 \\
\hline 28 & Tanjungbunga & 0.947 & 0.615 & -0.186 & 0.583 \\
\hline 29 & Tallasa & 0.990 & 0.210 & -0.048 & 0.208 \\
\hline 30 & Maros & 0.963 & 0.201 & -0.059 & 0.193 \\
\hline 31 & Punagaya & 1.000 & 0.000 & 0.000 & 0.000 \\
\hline 32 & Jeneponto & 0.979 & 0.182 & -0.035 & 0.178 \\
\hline 33 & Bulukumba & 0.988 & 0.278 & -0.067 & 0.274 \\
\hline 34 & Sinjai & 1.000 & 0.219 & -0.046 & 0.219 \\
\hline 35 & Bone & 0.994 & 0.325 & -0.083 & 0.323 \\
\hline 36 & Soppeng & 0.987 & 0.145 & -0.035 & 0.143 \\
\hline 37 & Sengkang & 1.020 & 0.273 & -0.111 & 0.278 \\
\hline 38 & Makale & 1.020 & 0.114 & -0.014 & 0.117 \\
\hline 39 & Palopo & 1.000 & 0.492 & 0.000 & 0.492 \\
\hline 40 & Latuppa & 0.972 & 0.000 & 0.000 & 0.000 \\
\hline 41 & Pltaposo & 1.000 & 0.000 & 0.000 & 0.000 \\
\hline 42 & Pamona275 & 0.993 & 0.000 & 0.000 & 0.000 \\
\hline 43 & Pamona150 & 0.989 & 0.050 & -0.005 & 0.050 \\
\hline & Poso & 0.986 & 0.113 & -0.019 & 0.112 \\
\hline & & & & $\mathbf{8 . 3 8}$ \\
\hline 1405 & & & \\
\hline
\end{tabular}

Tabel 2 menjukkan bahwa arus yang mengalir dari bus beban ke bus netral fiktif sebesar 8.381 (pu). Dengan menggunakan hukum kirchoff kemudian digunakan untuk menghitung besar arus yang mengalir dari bus netral fiktif ke bus load center.
Menentukan nilai impedansi Zlc dari bus netraf fiktif ke bus load center dengan menggunakan persamaan (III.5) sehingga didapat nilai Zlc = $0.1101+\mathrm{j} 0.0246$. Tegangan pada bus load center dihitung menggunakan persamaan (III.6) sehingga menghasilkan tegangan (Vlc) sebesar 0.9691 (pu) dengan sudut tegangan sebesar $0.0013^{\circ}$.

Setelah admitansi konstan dan arus setiap bus didapat, maka terlebih dahulu kita mengurutkan ulang penomoran bus dari 1 sampai 61. Bus 1 sampai bus 15 diisi dengan bus generator, bus 16 dengan bus load center, bus 17 dengan bus netral fiktif, bus 18 sampai bus 48 dengan bus beban, dan bus 49 sampai bus 61 dengan bus impedansi generator, sehingga nantinya akan terbentuk matriks 61 x 61. Eliminasi Gauss-Seidel diterapkan untuk mereduksi matriks 61 x 61 menjadi matriks 16 x 16. Admitansi konstan kemudian diubah menjadi impedansi untuk dipakai sebagai inputan nilai impedansi ekivalen dalam menjalankan load flow dengan 16 bus yang sudah direduksi, maka didapatkan indeks kestabilan sistem sebesar 6.8779 (pu), yang menyatakan sistem dalam keadaan stabil.

Selanjutnya dilakukan analisis transient pada 16 bus hasil reduksi menggunakan pendekatan metode REI-Dimo sehingga didapatkan bus terlemah pada sistem, tegangan rata-rata dan arus gangguan terbesar saat terjadi gangguan hubung singkat tiga fasa.

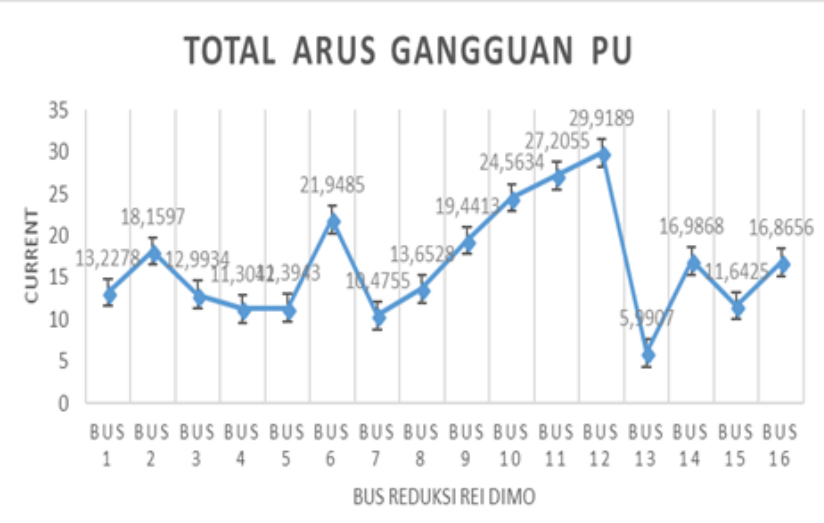

Gambar 6. Grafik radiasi di jeneponto

Gambar 6 memperlihatkan grafik total arus gangguan yang terjadi di 16 bus hasil reduksi REIDimo. Bus 13 (Makale) adalah bus yang memiliki arus total gangguan terkecil, disusul bus 7 (Tello 
Lama 150) di susul kemudian bus 4 (PLTU Barru), bus 5 (Tello 150), bus 15 (PLTU Poso) dan bus 3 (bus Suppa). Sementara total arus gangguan tertinggi berada pada bus 12 (Sengkang).

Tabel 3. Total arus gangguan

\begin{tabular}{ccc}
\hline $\begin{array}{c}\text { No } \\
\text { Bus }\end{array}$ & Nama Bus & $\begin{array}{c}\text { Curent } \\
\text { Foult Total }\end{array}$ \\
\hline 1 & bus bakaru & 13.2278 \\
\hline 2 & bus pinrang & 18.1597 \\
\hline 3 & bus suppa & 12.9934 \\
\hline 4 & bus pltu barru & 11.3042 \\
\hline 5 & bus tello150 & 11.3943 \\
\hline 6 & bus borongloe & 21.9485 \\
\hline 7 & bus tellolama150 & 10.4755 \\
\hline 8 & bus sungguminasa & 13.6528 \\
\hline 9 & bus tallasa & 19.4413 \\
\hline 10 & bus pgaya & 24.5634 \\
\hline 11 & bus sinjai & 27.2055 \\
\hline 12 & bus sengkang & 29.9189 \\
\hline 13 & bus makale & 5.9907 \\
\hline 14 & bus palopo & 16.9868 \\
\hline 15 & bus plta poso & 11.6425 \\
\hline 16 & Bus Load Center & 16.8656 \\
\hline
\end{tabular}

Tabel 3 menunjukkan total arus gangguan pada setiap busnya selama terjadi gangguan di bus tersebut. Ada 16 bus hasil reduksi yang di uji. Dari Tabel 3 dapat dilihat bahwa arus gangguan terbesar terjadi pada bus 12 (Sengkang) yakni sebesar 29.9189 pu.

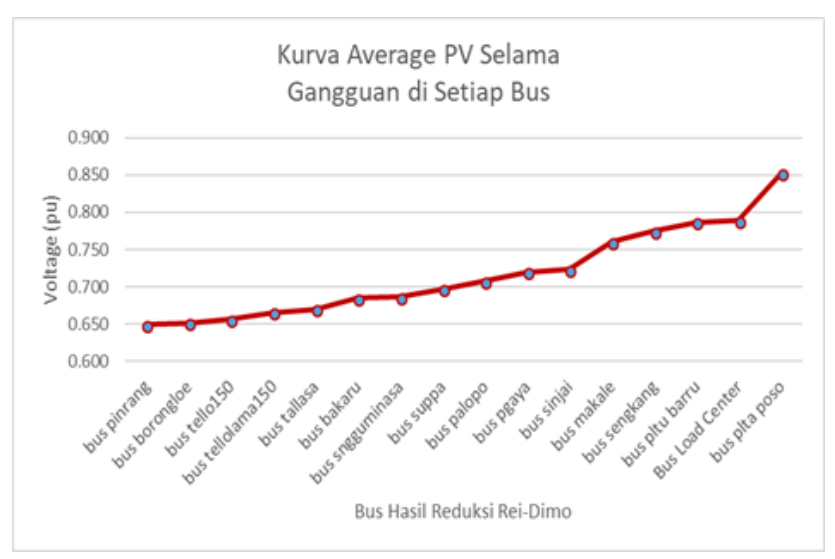

Gambar 7. Grafik profil tegangan setiap bus

Dari Gambar 7 dapat kita amati nilai degradasi profil tegangan, dan berdasarkan kurva tesebut penurunan tegangan tertinggi berada pada bus Pinrang disusul bus Borongloe, Tello 150, Tello Lama 150, Tallasa, Bakaru, Sungguminasa, Suppa, Palopo, Punagaya, Sinjai, Makale, Sengkang, PLTU Barru, bus Load Center dan terakhir bus PLTA Poso. Nilai dari rata-rata tegangan selama gangguan meyatakan bus Pinrang memiliki pengaruh signifikan ketika terjadi gangguan dengan nilai rata-rata degradasi tegangan sebesar $0.6492 \mathrm{pu}$.

\section{Kesimpulan}

Hasil dari analisis transient menggunakan pendekatan Radial Equivalent independent atau yang dikenal dengan Metode REI-Dimo menunjukkan arus total gagguan terbesar saat terjadinya gangguan di setiap bus-nya setelah mengalami proses reduksi menggunakan pendekatan REI-Dimo maka diperoleh bus generator 12-Sengkang memiliki nilai arus gangguan terbesar yakni $29.9189 \mathrm{pu}$, disusul bus generator 11-Sinjai 27.2055 pu dan bus generator 10-Punagaya-24.5634 pu.

Dengan menggunakan pendekatan REI-Dimo pula didapatkan 3 bus generator yang memiliki profil tegangan terendah selama gangguan. Masing-masing adalah bus generator 2-Pinrang $0.6492 \mathrm{pu}$ disusul bus generator 6-Borongloe 0.6513 pu dan bus generator 5-Tello150 sebesar $0.6566 \mathrm{pu}$. Sementara 4 bus dengan profil tegangan terbesar yakni bus generator 15-PLTA Poso 0.8521 pu, bus 16-Load Center 0.884 pu, bus generator 4PLTU Barru $0.7865 \mathrm{pu}$, serta bus generator 12Sengkang $0.7746 \mathrm{pu}$.

\section{Referensi}

[1] Anju G Pillai, Thomas PC., Sreerenjini K., Sarin baby., Sasidhran Sreedharan., 2013. Transient stability analysis of wind integrated power systems with storage using central area controller BT - 2013 Annual International Conference on Emerging Research Areas, AICERA 2013 and 2013 International Conference on Microelectronics, Communicatio. Int. J. Sci. Eng. Res., vol. 4, no. 8, p. Amal Jyothi College of Engineering; Defence Resear, 2013.

[2] Indar C.G, Soeprijanto, A., and Penangsang, O., 2012. Steady State Stability Assessment Using Extreme Learning Machine Based on Modal Analysis. International Review of Electrical Engineering, June 2012. 
[3] Gamit M.G., Jigar, S.,S., 2015. Transient Stability Analysis on a Multi-Machine System in Psat. Int. J. Res. Eng. Technol., vol. 4, no. 3, pp. 604-613.

[4] Indar C.G., Sri, M.S., and Muhammad, I., 2016. Determination of stability index of electrical power system using REI-Dimo methods. J. Theor. Appl. Inf. Technol., vol. 90, no. 1, pp. 161-167.

[5] N. Anil Kumar, K. Ramesh., 2007. Transient stability improvement using upfc and svc 1. vol. 2, no. 3, pp. 3845.

[6] Federico, M., 2005. An Open Source Power System Analysis Toolbox. vol. 20, IEEE Transaction On Power Systems, pp. 1199-1206, Vol. 20, No. 3.

[7] Ardiaty, A \& Muhammad B.N., 2016. Voltage Drop Simulation at Southern Sulawesi Power System
Considering Composite Load Model. In ICITACEE. pp. 169-172.

[8] Wilson R., Rakibuzzaman S,. Dkk., 2014. Expanding Power System Analysis Toolbox (PSAT) Functionalities for Better Result Interpretation. Australasian Universities Power Engineering Conference, (October), pp.1-6.

[9] Chaerah Gunadin, Indar, dkk., 2011. Steady-State Stability Assesment Using Neural Network Based on Network Equivalent. TELKOMNIKA, Vol.9, No.3, pp. 411-422.

[10] Rusilawati., 2015. Penentuan Batas Kestabilan Steady State Generator dengan Konsep REI-Dimo. Seminar Nasional Inovasi dalam Desain dan Teknologi”IDeaTech, pp.9-17. 